\title{
Feeding behaviour and caecotrophy in the rabbit after isolation of the caecum
}

\author{
F. GALLOUIN, G. DEMAUX, H. LE BARS et L. GUEMON \\ Laboratoive de la Chaive de Physiologie Animale, \\ I.N.A. Paris Grignon, I6, rue Claude-Bernard, \\ 75005 Paris (France)
}

In six New Zealand white rabbits weighing $2560 \pm 370 \mathrm{~g}$, the caecum was isolated by a ligature above the ileo-caecal valve which therefore still functioned. In order to let the caecum void, it was caecostomied up to the skin.

After caecum isolation, the two types of faecal excretions persisted. The morphology of the caecotrophes was not very different, but their volatile fatty acid (VFA) contents was significantly different from that of the caecotrophes excreted by normal rabbits. Part of the caecotrophes were not consumed for about 21 days by the rabbits operated on. After this period, no more caecotrophes could be found on the litter. The autopsy made 35 days after the operation revealed that a new caecum had developed. Our results agree with those obtained by HFRNDoN J. F. and Hove E. L. (I955) then by BACQtès C. and PERRIT J. (I97I) who first observed that caecectomy suppresses caecotrophy, but no the duality of faecal excretion.

Our results suggest that the new caecum is sufficient to produce genuine caecotrophes which are hence ingested by the rabbit. During the experimental period the feed consumption of the rabbits was not very different from that of normal rabbits.

\section{Changes in the quantitative microflora, faecal excretion and intestinal transit in the rabbit after ligature of the pancreatic duct}

\author{
Jacqueline CATALA et $\mathrm{R}$. BONNAFOUS \\ Institut de Physiologie, \\ 2, vue François-Magendie, \\ 3 I 400 Toulouse (France)
}

In the rabbit, ligature of the pancreatic duct induced four days after the operation an increase in the amount of microorganisms in the caecotrophes. The induction of this bacterial proliferation did not depend on caecotrophy, but more likely on the arrival in the caecum of a material richer in nutrients not attacked by the pancreatic juice. Even though caecotrophy was not directly involved in the proliferation of microorganisms, it was required for maintaining this phenomenon. This resulted in an increased excretion of faeces both the hard ones and the caecotrophes. The amount of caecotrophes reingested by the rabbits with ligated pancreas was $38 \mathrm{p}$. Ioo higher than that observed in normal rabbits, resulting in a slowing down of the intestinal transit. 